\title{
THROMBOCYTOPENIA AS ONE OF THE REASONS OF PROLONGED STAY IN THE NEONATAL INTENSIVE CARE UNIT
}

\author{
Zulić Evlijana, Hadžić Devleta \\ Clinic for Children's Diseases, University Clinical Centre Tuzla, Tuzla, Bosnia and Herzegovina \\ Primljen/Received 25. 07. 2019. god. \\ Prihvaćen/Accepted 02. 10. 2019. god.
}

\begin{abstract}
The aim of this paper was to present the occurrence and severity of thrombocytopenia, with intracranial and another bleeding in neonates with sepsis, analyze the risk factors for the development of thrombocytopenia and compare it with the length of hospitalization in the Neonatal Intensive Care Unit (NICU). Thrombocytopenia is a platelet count $<150 \times 109 / \mathrm{L}$ and is common in newborns during hospitalization in the NICU. In the early days of life, the most common causes of thrombocytopenia in newborns are conditions that lead to fetal hypoxia, intrauterine growth failure, maternal hypertension, and sepsis. In this study were included all newborns with thrombocytopenia, who were hospitalized in NICU, Children's Disease Clinic, University Clinical Centre in Tuzla, from 01. 01.2014 to 01.01 .2019$.
\end{abstract}

In our results, 379 newborns had severe, 337 moderate, and 127 milder forms of thrombocytopenia, without a statistically significant difference in the incidence of thrombocytopenia between groups of neonates born $<37 \mathrm{GW}$ and $\geq 37 \mathrm{GW}$. Sepsis was the most common cause of thrombocytopenia, 300 children had early sepsis and 190 late. We found the statistically significant difference in intracranial hemorrhage of the second degree and pulmonary hemorrhage among neonates born $<37 \mathrm{GW}$ in relation to newborns born $\geq 37 \mathrm{GW}$. A statistically significant effect of length of stay of our neonates in the Department of Neonatal Intensive Therapy and morbidity was shown in relation to the lower gestational age and lower platelet counts.

Conclusion: Timely diagnosis of the cause and development of thrombocytopenia with adequate and effective treatment can reduce the mortality and morbidity of newborns with perinatal risk for neonatal thrombocytopenia.

Key words: thrombocytopenia, newborn, sepsis, neonatal intensive care unit.

\section{INTRODUCTION}

Thrombocytopenia by definition is reduced platelet count $<150 \times 109 / \mathrm{L}$ and frequent finding in neonates during hospitalization in the Neonatal Intensive Care Unit (NICU) (1). Despite a large number of studies, thrombocytopenia in the newborn is still in the focus of interest, due to possible complications resulting from a reduced number of platelets, such as various bleeding, especially intracranial and necrotizing enterocolitis, with possible fatal outcome (2).

In the first days of life, the most common causes of thrombocytopenia in neonates are antibodies mediated by platelet destruction, intrauterine growth retardation, and maternal hypertension, along with other factors associated with chronic fetal hypoxia. Antibodies mediated by platelet destruction are further classified into neonatal alloimmune thrombocytopenia when the mother's antibodies recognize fetal platelets as foreign and destroy them. However, it also could be a passive transfer of maternal autoantibodies that are produced in the mother due to the existence of an autoimmune disease, such as systemic lupus or immune thrombocytopenic purpura, when the platelets are also destroyed.

One of the main causes of thrombocytopenia in NICU is sepsis, during which middle-to-severe thrombocytopenia occurs in the period from 24 to 48 hours from the first signs of infection (3). Congenital infections, the causative agents of toxoplasmosis, measles, cytomegalovirus, herpes simplex virus, and fungal infections are also possible causes of thrombocytopenia in the neonatal period.

The thrombocytopenia pathogenesis and platelet count in neonatal sepsis have not yet been fully clarified, nor did the exact number of platelets, by which bleeding occurs. A possible mechanism of bleeding is damage to the blood vessel endothelium that activates the reticuloendothelial platelet damage system. Throm- 
bocytopenia occurs when it is a higher consumption than platelet production, with the particular role of reduced serum thrombopoietin (1).

Thrombocytopenia, that occurs within the first 72 hours of birth is early, compared to late, which occurs after 72 hours of birth. In relation to the platelet count, it may be severe form $<30 \times 109 / \mathrm{L}$, a moderate form of 31 to $100 \times 109 / \mathrm{L}$, and a milder form of 101 to $150 \mathrm{x}$ 109/L (4, 5).

The aim of this paper was to present the occurrence and severity of thrombocytopenia, with intracranial and another bleeding in neonates with sepsis, analyze the risk factors for the development of thrombocytopenia and compare it with the length of hospitalization in the Neonatal Intensive Care Unit.

\section{SUBJECTS AND METHODS}

All newborns with thrombocytopenia, who were hospitalized in the Department of Neonatal Intensive Care Unit, the Clinic for Children's Diseases, University Clinical Centre in Tuzla, in the period from 01. 01 . 2014 to 01.01 .2019 were included in this study. Data are collected from the history of neonatal disease. The research was approved by the Ethics Committee, University Clinical Centre in Tuzla.

Data on hypertension, the number and the order of pregnancy, and the way of ending the delivery were collected from the mother's history of the disease. Maternal hypertension was defined when systolic blood pressure was higher than $140 \mathrm{mmHg}$, diastolic 90 $\mathrm{mmHg}$ or more, in more than two measurements, or once measured with values greater than 160/110 $\mathrm{mmHg}$.

The children's history of the disease has been reported data of gestational age, birth weight, gender, day of occurrence and duration of thrombocytopenia,severe bleeding and length of hospitalization.

Of the hematological data for each child, the initial platelet count was observed in the occurrence of sepsis and the lowest number of platelets over the duration of the sepsis. The clinical diagnosis of sepsis was confirmed by a positive finding of blood culture.

The exclusion criteria of this study were for newborns, who had a good general condition in the first 24 hours, with the excluded clinical diagnosis of sepsis, and were moved to another department, or had a contaminated blood culture, i.e. positive blood culture, without an increase in $\mathrm{C}$ - reactive protein and no antibiotic treatment in the first 72 hours.

All data were statistically processed and displayed using tables and images. The standard methods of descriptive statistics were used in the analysis. Absolute numbers and percentages were used to describe categorical data. The mean value \pm standard deviation, or median, was used to describe numerical data. Statistical data analysis was carried out using the statistical program SPSS (version 17, StatSoft, Tulsa, USA).

\section{RESULTS}

This study included 843 newborns with thrombocytopenia, $536(41.3 \%$ ) born $<37 \mathrm{GW}$ (week of gestation), and 307 (27\%) born $\geq 37 \mathrm{GW}$. The prevalence of thrombocytopenia in preterm births was $6.5 \%$ $(843 / 1296)$ compared to the previous 5 years. Most of our neonates, 489 (58.6\%) had early thrombocytopenia. There was no statistically significant difference in the incidence of thrombocytopenia between groups of neonates born $<37 \mathrm{GW}$ and $\geq 37 \mathrm{GW}$. Table 1 isthe epidemiological date of newborns with thrombocytopenia born $<37 \mathrm{GW}$ and born $\geq 37 \mathrm{GW}$ (Table 1).

In our study, 379 newborns had severe, 337 moderate, and 127 milder forms of thrombocytopenia (Figure 1).

Table 2 shows the perinatal data of neonates with thrombocytopenia. The average mother's age of children with thrombocytopenia born $<37 \mathrm{GW}$ was $24 \pm$ 3.2 , while for children born $\geq 37 \mathrm{GW}$ was $28.2 \pm 4.1$ years. Hypertension had $61.8 \%$ of mothers in the group

Table 1. Newborns with thrombocytopenia born $<37 \mathrm{GW}$ and $\geq 37 \mathrm{GW}$

\begin{tabular}{|c|c|c|c|c|c|}
\hline \multirow{2}{*}{ Birth year } & \multirow{2}{*}{$\begin{array}{c}\text { Total number } \\
\text { of births } \\
(<37 \mathrm{GW} / \\
>37 \mathrm{GW})\end{array}$} & \multicolumn{2}{|c|}{$\begin{array}{c}\text { Newborns with thrombocytopenia } \\
\text { born }<37 \mathrm{GW}\end{array}$} & \multicolumn{2}{|c|}{$\begin{array}{c}\text { Newborns with thrombocytopenia } \\
\text { born } \geq 37 \mathrm{GW}\end{array}$} \\
\cline { 3 - 6 } & $(\mathrm{n} ; \%)$ & $\begin{array}{c}\text { Time of sepsis } \\
\text { onset } \\
\text { (early/late) }\end{array}$ & $\begin{array}{c}\text { Time of sepsis } \\
\text { onset } \\
(\text { early/late })\end{array}$ \\
\hline 2014 & $195(130 / 65)$ & $78(40 \%)$ & $50 / 28$ & $40(20.5 \%)$ & $29 / 11$ \\
\hline 2015 & $180(111 / 69)$ & $87(48.3 \%)$ & $50 / 37$ & $35(19.4 \%)$ & $19 / 16$ \\
\hline 2016 & $247(149 / 98)$ & $105(42.5 \%)$ & $75 / 30$ & $60(24.3 \%)$ & $30 / 30$ \\
\hline 2017 & $332(182 / 150)$ & $116(35 \%)$ & $70 / 46$ & $82(25 \%)$ & $40 / 42$ \\
\hline 2018 & $342(172 / 170)$ & $150(44 \%)$ & $85 / 65$ & $90(26.3 \%)$ & $41 / 49$ \\
\hline Ukupno & $1296(747 / 522)$ & $536(41.3 \%)$ & $330 / 206$ & $307(27 \%)$ & $159 / 128$ \\
\hline
\end{tabular}


Table 2. Perinatal data of neonates with thrombocytopenia

\begin{tabular}{|l|c|c|}
\hline \multicolumn{1}{|c|}{ Perinatal data } & $\begin{array}{c}\text { Number of newborns with } \\
\text { thrombocytopenia born } \\
<37 \mathrm{GW}\end{array}$ & $\begin{array}{c}\text { Number of newborns with } \\
\text { thrombocytopenia born } \\
\geq 37 \mathrm{GW}\end{array}$ \\
\hline Mother's age (years) & $24 \pm 3.2(14-47)$ & $28.2 \pm 4.1(15-45)$ \\
\hline Mother's hypertension & $310(57.8 \%)$ & $190(61.8 \%)$ \\
\hline Number of pregnancy & $2(1-5)$ & $2(1-6)$ \\
\hline Multiple pregnancy & $92(17.2 \%)$ & $34(11 \%)$ \\
\hline Intrauterine growth of retardation & $173(32.3 \%)$ & $148(48.2 \%)$ \\
\hline Caeserian section & $328(61.2 \%)$ & $170(55.9 \%)$ \\
\hline Age of gestation (week of gestation) & $30 \pm 3.9(24-36)$ & $38.2 \pm 2.1(37-42)$ \\
\hline Birth weight (gram) & $1010 \pm 234(455-2500)$ & $3550 \pm 456(2950-5010)$ \\
\hline Gender (male/female) & $80: 55(15: 10 \%)$ & $150: 197(49: 64 \%)$ \\
\hline Apgar score after 1 minute & $4(0-9)$ & $6(0-9)$ \\
\hline Apgar score after 5 minute & $8(0-9)$ & $9(0-9)$ \\
\hline
\end{tabular}

*Data is represented by a number as $\mathrm{n}(\%)$ or median (space)

Table 3. Causes of thrombocytopenia in neonates

\begin{tabular}{|l|c|c|c|}
\hline Causes of thrombocytopenia & $\begin{array}{c}\text { Number of newborns with } \\
\text { thrombocytopenia born } \\
<37 \mathrm{GW}\end{array}$ & $\begin{array}{c}\text { Number of newborns with } \\
\text { thrombocytopenia born } \\
\geq 37 \mathrm{GW}\end{array}$ & P values \\
\hline Sepsis & $300(55.9 \%)$ & $190(62 \%)$ & 0.268 \\
\hline Early onset of sepsis & $180(33.5 \%)$ & $120(39 \%)$ & 0.112 \\
\hline Late onset of sepsis & $120(22.3 \%)$ & $70(11 \%)$ & 0.534 \\
\hline Perinatal asphyxia & $530(98 \%)$ & $268(87.2 \%)$ & 0.065 \\
\hline Necrotizing enterocolitis & $88(16.4 \%)$ & $10(30.7 \%)$ & 0.068 \\
\hline Chromosomal abnormalities & $13(2.4 \%)$ & $20(6.5 \%)$ & 0.876 \\
\hline
\end{tabular}

Table 4. Hemorrhagic diathesis in neonates with thrombocytopenia

\begin{tabular}{|l|c|c|c|}
\hline \multicolumn{1}{|c|}{ haemorrhage } & $\begin{array}{c}\text { Number of newborns with } \\
\text { thrombocytopenia born } \\
<37 \mathrm{GW}\end{array}$ & $\begin{array}{c}\text { Number of newborns with } \\
\text { thrombocytopenia born } \\
\geq 37 \mathrm{GW}\end{array}$ & $\mathrm{p}$ \\
\hline Intracranial haemorrhage grade I & $54(10 \%)$ & $30(9.7 \%)$ & 0.322 \\
\hline Intracranial haemorrhage grade II & $250(46.7 \%)$ & $250(81.4 \%)$ & $0.040^{*}$ \\
\hline Intracranial haemorrhage grade III & $32(5.9 \%)$ & $37(12 \%)$ & 0.644 \\
\hline Cutaneus bleeding & $98(18.2 \%)$ & $60(19.5 \%)$ & 0.342 \\
\hline Pulmonal haemorrhage & $169(31 \%)$ & $20(6.5 \%)$ & $0.003^{*}$ \\
\hline Haematuria & $2(0.3 \%)$ & $1(0.3 \%)$ & 0.675 \\
\hline Gatrointestinal haemorrhage & $23(4,2 \%)$ & $10(3 \%)$ & 0.546 \\
\hline
\end{tabular}

of births $\geq 37 \mathrm{GW}$. In both groups, children with thrombocytopenia were from second pregnancy, and in the group of children $<37 \mathrm{GW}, 17.2 \%$ were from multiple pregnancies. Although $48.2 \%$ of children with thrombocytopenia who was born $\geq 37 \mathrm{GW}$ had an intrauterine delay in growth, the incidence of cesarean section was greater in the birth group $\geq 37 \mathrm{GW}$. Newborns with thrombocytopenia in the group $<37 \mathrm{GW}$ are born in 30 $\pm 3.9 \mathrm{GW}$, with a birth weight of $1010 \pm 234$ grams, and in the group $\geq 37 \mathrm{GW}$ at $38.2 \pm 2.1 \mathrm{GW}$ and $3550 \pm 456$ grams. The higher incidence of males was seen in the group of children $<37 \mathrm{GW}$ and lower Apgar score. 


\section{Thrombocytopenia}

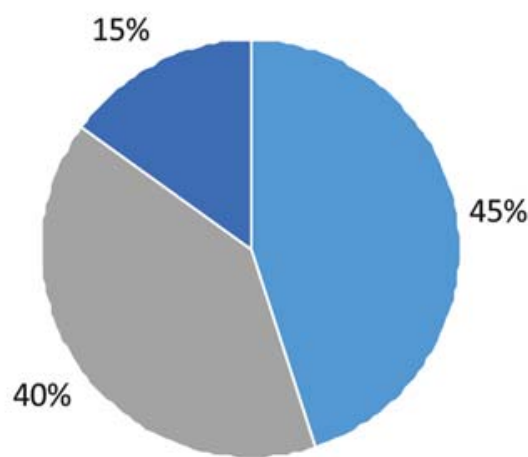

* Severe thrombocytopenia 45\% (platelets $<30 \times 109 / \mathrm{L}$ ), moderate $40 \%$ (platelets 31 to $100 \times 109 / \mathrm{L}$ ), mild $15 \%$ (platelets > 101 to $150 \times 109 / \mathrm{L})$.

\section{Figure 1. Thrombocytopenia in our neonates}

The causes of neonatal thrombocytopenia are shown in Table 3. Sepsis was the most common cause of thrombocytopenia, 300 children had early sepsis and 190 late. Thrombocytopenia was associated with sepsis, necrotizing enterocolitis, perinatal asphyxia, and chromosomal abnormalities, with no statistically significant difference between neonates born $<37$ or $\geq$ $37 \mathrm{GW}$.

In Table 4, the rates of intracranial and another bleeding of neonates with thrombocytopenia in relation to gestational age are shown. We found the statistically significant difference in intracranial hemorrhage of the second degree $(p=0.04)$ and pulmonary hemorrhage $(0.003)$ among neonates born $<37 \mathrm{GW}$ in relation to newborns born $\geq 37 \mathrm{GW}$.

A two-factor analysis of the variance of neonates with thrombocytopenia has shown the effect of the platelet count and gestational age on the length of hospita-

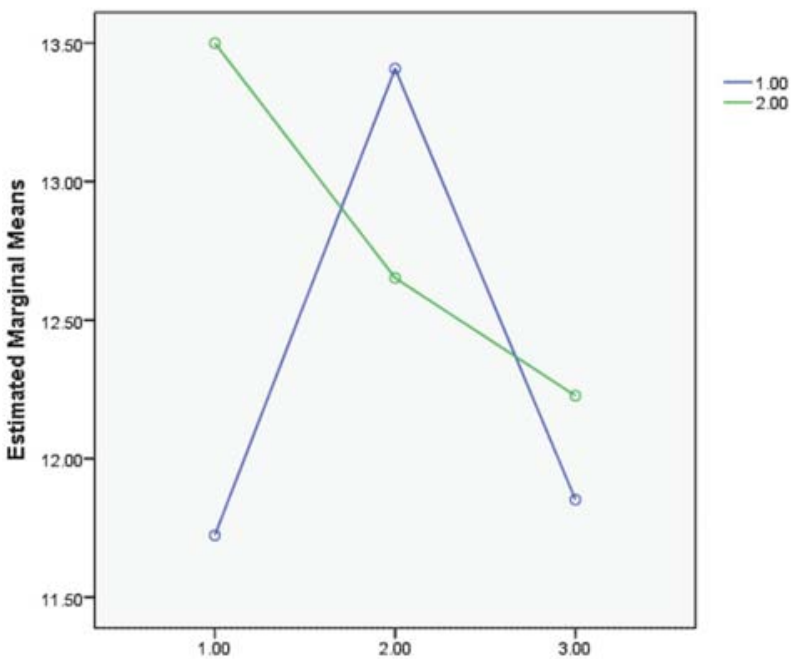

Figure 2. Effect of the platelet count and gestational age on the length of hospitalization in NICU of the neonates with thrombocytopenia lization in the NICU and the state of morbidity (Figure $2)$. Newborn infants are divided by gestational age into two groups (1 group $<37 \mathrm{GN}, 2$ groups $\geq 37 \mathrm{GN}$ ) and platelet counts (group $1<30 \times 109 / \mathrm{L}$, group 2 from 31 to $100 \times 109 / \mathrm{L}$, and 3rd group 101 to $150 \times 109 / \mathrm{L}$ ). The effect of interaction between gestational age and platelet count was not statistically significant, F $(2,290)=1.44, p=0.74$. A statistically significant influence of the length of stay in NICU and morbidity of newborns in relation to younger gestational age and lower platelet count $\mathrm{F}(0.873)=2.91, \mathrm{p}=0.002$ was determined.

\section{DISCUSSION}

Thrombocytopenia in the neonatal period is a common problem. During our research, it was recorded in more than half of newborns (68.3\%). In $45 \%$ of newborns, severe thrombocytopenia has been diagnosed. Most of our neonates, 489 (58.6\%) had early thrombocytopenia, but without a statistically significant difference in the incidence of thrombocytopenia between groups of neonates born $<37$ GN and $\geq 37$ GN. The Dutch authors presented similar results in their research (6).

The average of mother's age of children with thrombocytopenia born $<37 \mathrm{GN}$ was $24 \pm 3.2$, while for children born $\geq 37 \mathrm{GN}$ was $28.2 \pm 4$.1 years. Hypertension had $61.8 \%$ of mothers in the group of children born $\geq 37$ GN. In both groups, children with thrombocytopenia were from second pregnancy. In the group of children $<37 \mathrm{GN}, 17.2 \%$ were from multiple pregnancies. A higher percentage of $48.2 \%$ of children with thrombocytopenia born $\geq 37 \mathrm{GN}$ had intrauterine growth retardation, while a higher incidence of cesarean sections had newborns in the group of $\geq 37$ GN. Newborns with thrombocytopenia in the group $<37$ $\mathrm{GN}$ are generally born in $30 \pm 3.9 \mathrm{GN}$, with a birth weight of $1010 \pm 234$ grams, and in the group $\geq 37 \mathrm{GN}$ at $38.2 \pm 2.1 \mathrm{GN}$ and $3550 \pm 456$ grams. The higher incidence of males was seen in the group of children $<37$ GN and lower Apgar score. According to the data of a large retrospective cohort study (7), Resch et al. proved that neonatal thrombocytopenia is directly related to maternal hypertension and the elderly age of birth, also more frequent in prematurely born children, with lower birth weight and lower Apgar scores, which we had during our research.

Thrombocytopenia was associated with sepsis, necrotizing enterocolitis, perinatal asphyxia, and chromosomal irregularities, with no statistically significant difference between neonates born $<37$ GN or $\geq 37$. Bleeding was diagnosed in 443 (50\%) infants. The incidence of caesarean section in newborns with sepsis 
and thrombocytopenia can be explained by the higher incidence of maternal hypertension and the risk of birth naturally. It is known that maternal hypertension, in addition to being a risk factor for the development of neonatal thrombocytopenia, is a possible risk factor for intrauterine growth retardation. Also, maternal hypertension leads to fetal hypoxia and causes suppression of fetal megakaryocytopoiesis and platelet production. According to a study by British authors (8) and central venous catheters, they cause mechanical damage to the blood vessel, which directs the flow of blood in the other direction into the vascular wall sections that damage the megakaryocytopoiesis process.

Inthe newborns with thrombocytopenia intracranial, bleeding in the skin, pulmonary and gastrointestinal bleeding and hematuria were often, but statistically, a significant difference was found in intracranial hemorrhage of the second degree $(p=0.04)$ and pulmonary hemorrhage (0.003) among neonates born $<37 \mathrm{GN}$ in relation on newborns born $\geq 37 \mathrm{GN}$.

The association between the number of platelets and clinically manifest bleeding complications is still not fully clarified. The incidence of association of major manifest bleeding and severe thrombocytopenia in several different authors ranges from $15 \%$ to $50 \%$ (9, $10)$. The risk of occurrence of manifest bleeding is associated with lower gestational age, but a small number of platelets is not yet an indicator or measure of severe manifest bleeding in a child $(10,11)$.

In several different studies, the association between thrombocytopenia and gram-negative sepsis was found $(12,13)$. The number of platelets is significantly lower in gram-negative sepsis and sepsis caused by fungi, compared with gram-positive sepsis. According to research by Ahmed F et al. the duration of thrombocytopenia in gram-positive sepsis is also lower compared to gram-negative (14). The pathogenesis of thrombocytopenia in neonatal sepsis has not yet been fully clarified. Thrombocytopenia should be a predictor of the severity of sepsis, the more gram-negative than gram-positive, as it causes intravascular disseminated coagulopathy (12). An important mechanism of action of endotoxin in gram-negative bacteria is important.

During our research, a statistically significant difference was found on the length of stay in NICU and morbidity of neonates compared to younger gestational age and lower platelet counts, as was confirmed by other authors in their research $(13,14,15)$.

However, further and more detailed research is needed to help determine the exact number of platelets as a predictor of possible bleeding and prevention of sepsis and mortality in newborns, as well as longer hospitalization in the NICU.

\section{CONCLUSION}

Thrombocytopenia is often diagnosed in the neonatal period. Most episodes are mild or moderate and usually pass without major clinical consequences for the newborn. However, severe thrombocytopenia also causes serious consequences and is associated with longer hospitalization and more frequent child mortality. Early birth, sepsis, and perinatal asphyxia are the most common causes of neonatal thrombocytopenia. A timely diagnosis of the cause of thrombocytopenia with adequate and effective treatment can reduce the mortality and morbidity of newborns with perinatal risks for the development of neonatal thrombocytopenia.

\section{Abbreviations \\ NICU - Neonatal Intensive Care Unit \\ GW - week of gestation}

Acknowledgment: None

Conflict of Interests: The authors declare that there are no conflicts of interest related to this article.

Funding: None

\section{Licensing}

This work is licensed under a Creative Commons Attribution 4.0 International (CC BY 4.0) License.

\title{
Sažetak
}

\section{TROMBOCITOPENIJA KAO JEDAN OD RAZLOGA PRODUŽENE HOSPITALIZACIJE NA ODELJENJU NEONATALNE INTENZIVNE NEGE}

\author{
Zulić Evlijana, Hadžić Devleta \\ Clinic for Children's Diseases, University Clinical Centre Tuzla, Tuzla, Bosnia and Herzegovina
}

Cilj ovog rada je bio uporediti pojavu i težinu trombocitopenije, uz intrakranijalno i druga krvarenja kod novorođenčadi sa sepsom, te analizirati faktore rizika za nastanak i razvoj trombocitopenije i duži- ne hospitalizacije na Odeljenju neonatalne intenzivne terapije.

Trombocitopenija je broj trombocita $<150 \mathrm{x}$ 109/L i čest je nalaz kod novorođenčadi tokom hospi- 
talizacije na Odeljenju neonatalne intenzivne terapije. U prvim danima života najčešći razlozi trombocitopenije kod novorođenčadi su stanja koja dovode do fetalne hipoksije, intrauterinog zastoja u rastu, majčina hipertenzija i sepsa. U ovo istraživanje su uključena sva novorođenčad sa trombocitopenijom, koja su bila hospitalizovana na Odeljenju neonatološke intenzivne terapije, Klinike za dečije bolesti, JZU UKC Tuzla, u periodu od 01. 01. 2014. do 01. 01. 2019. godine.

Rezultatima smo pokazali da je 379 novorođenčadi imalo tešku, 337 umerenu, a 127 blaži oblik trombocitopenije, bez statistički značajne razlike u učestalosti trombocitopenije između grupa novorođenčadi rođenih $<37 \mathrm{GN}$ i $>37$ GN. Sepsa je bila najčešći razlog trombocitopenije, 300 dece je imalo ranu, dok 190

\section{REFERENCES}

1. Ree IMC, Fustolo-Gunnink SF, Bekker V, Fijnvandraat KJ, Steggerda SJ, Lopriore E. Thrombocytopenia in neonatal sepsis: Incidence, severity and risk factors. PLoS One. 2017; 12(10): e0185581.

2. Roberts I, Stanworth S, Murray NA. Thrombocytopenia in the neonate. Blood Rev. 2008; 22(4): 173-86.

3. Murray NA, Howarth Lj, McCloy MP, Letsky EA, Roberts IA. Platelet transfusion in the management of severe thrombocytophenia in neonatal intensive care unit patients. Transfus Med. 2002; 12(1): 35-41.

4. Levit O, Bhandari V, Li FY, Shabanova V, Gallagher PG, Bizzarro MJ. Clinical and laboratory factors that predict death in very low birth weight infants presenting with late-onset sepsis. Pediatr Infect Dis J. 2014; 33(2): 143-6.

5. Sola- Visner M, Saxonhouse MA, Brown RE. Neonatal thrombocytopenia: what we do and do not know. Early Hum Dev. 2008; 84(8): 499-506.

6. Fustolo-Gunnink SF, Fijnvandraat K, Putter H, Ree IM, Caram-Deelder C, Andriessen P, et al. Dynamic prediction of bleeding risk in thrombocytopenic preterm neonates. Haematologica. 2019; 104(11): 2300-6.

7. Resch E, Hinkas O, Urlesberger B, Resch B. Neonatal thrombocytopenia - causes and outcomes following platelet transfusions. Eur J Pediatr. 20018; 177(7): 1045-52. kasnu sepsu. Kod novorođenčadi rođene $<37$ GN u odnosu na novorođenčad rođenu $>37 \mathrm{GN}$ nađena je statistički značajna razlika kod intrakranijalnog krvarenja drugog stepena i plućnog krvarenja.Utvrđen je statistički značajan uticaj dužine boravka na Odeljenju neonatalne intenzivne terapije i morbiditeta novorođenčadi u odnosu na mlađu gestacijsku dob i niže vrednosti trombocita.

Zaključak: Pravovremeno dijagostikovanje razloga nastanka trombocitopenije uz adekvatno i pravovremeno lečenje može smanjiti smrtnost i morbiditet novorođenčadi sa perinatalnim rizicima za nastanak neonatalne trombocitopenije.

Ključne reči: trombocitopenija, novorođenčad, sepsa, Neonatalna Intenzivna terapija.

8. Carr R, Kelly AM, Williamson LM. Neonatal thrombocytopenia and platelet transfusion - a UK perspective. Neonatology. 2015; 107(1): 1-7.

9. Metha P, Vasa R, Neumann L, Karpatkin M. Thrombocytopenia in the high-risk infant. J Pediatr. 1980; 97(5): 791-4.

10. Baer VL, Lambert DK, Henry E, Christensen RD. Severe thrombocytopenia in the NICU. Pediatrics. 2009; 124(6): 1095-100.

11. Christensen RD, Bear VL, Henry E, Snow GL, Butler A, Sola-Visner MC. Thrombocytopenia in small-for-gestation-age infants. Pediatrics. 2015; 136(2): 361-70.

12. Ulsoy E, Tufekci O, Duman N, Kumral A, Irken $\mathrm{G}$, Oren H. Thrombocytopenia in neonates: causes and outcomes. Ann Hematol. 2013; 92(7): 961-7.

13. von Lindern J, van de Bruele T, Loprioere E, Walther F. Thrombocytopenia in neonates and risk of intraventricular hemorrhage: a retrospective cohort study. BMC Pediatr. 2011; 11:16.

14. Ahmed F, Raj AY, Begum LN. Thrombocytopenia in late-onset neonatal sepsis and its relationship with the specific organism in a tertiary care hospital. Mymensingh Med J. 2017; 26(4): 900-5.

15. Saxonhouse MA, Manco-Johnson MJ. The evaluation and management of neonatal coagulation disorders. Semin Perinatol. 2019; 33(1): 52-65.

\section{Correspondence to/Autor za korespondenciju}

Evlijana Zulić

Clinic for Children's Diseases, University Clinical Centre Tuzla

email: evlijanah@gmail.com

tel: +38761887721 